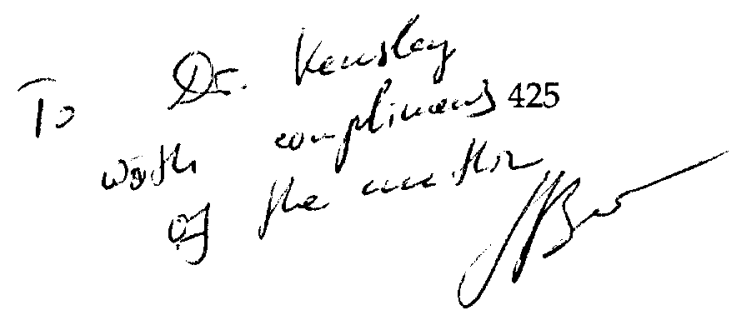

\title{
A NEW FAMILY FOR A DEEP-SEA CARIDEAN SHRIMP FROM NORTH ATLANTIC HYDROTHERMAL VENTS
}

\section{A.L. VERESHCHAKA}

P.P. Shirshov Institute of Oceanology, Russian Academy of Sciences, Krasikova Street 23, Moscow 117851, Russia

Mirocaris keldyshi gen. nov., sp. nov. is described from the Mid-Atlantic Ridge, TAG Location $\left(26^{\circ} 09^{\prime} \mathrm{N} 44^{\circ} 50^{\prime} \mathrm{W}\right)$. The family Mirocarididae is proposed to include the new genus. The taxonomic position and distinguishing characters (presence of hook-bearing thoracic epipods and rudimentary appendix interna on pleopods 2-4) of the new family as compared to the other families of the superfamily Bresilioidea (Bresiliidae, Disciadidae, and Alvinocarididae) are discussed, and revised diagnoses for these families are provided.

\section{INTRODUCTION}

Hydrothermal vent communities continue to provide us with new biological surprises in the form of undescribed families, genera and species. This is true for the relatively conspicuous and well-documented shrimp fauna from well-studied locations on the north Mid-Atlantic Ridge such as the TAG and Broken Spur vent sites. These recent discoveries are to a great extent due to the use of deep-sea manned submersibles, which allow precise sampling of different microbiotopes.

Recent collections have resulted in the discovery and description of several distinctive new shrimp taxa, such as Alvinocaris (Williams \& Chace, 1982) and members of three other new genera, Rimicaris, Chorocaris, and Opaepele (Williams \& Rona, 1986; Williams, 1988; Martin \& Hessler, 1990; Martin \& Christiansen, 1995; Williams \& Dobbs, 1995).

\section{MATERIALS AND METHODS}

The present material was taken during the 34th cruise of RV 'Akademik Mstislav Keldysh', conducted as part of the British-Russian Programme BRAVEX-94, August October 1994, with the use of two deep-sea manned research vessels (DSRV) 'Mir-1' and 'Mir-2' at two locations of the Mid-Atlantic Ridge: TAG $\left(\sim 26^{\circ} \mathrm{N}\right)$ and Broken Spur $\left(\sim 29^{\circ} \mathrm{N}\right)$. The ship and submersibles belong to the P.P. Shirshov Institute of Oceanology, Moscow, Russian Academy of Sciences.

Shrimps were collected using baited traps left on the bottom for a period of five days, the traps were positioned and retrieved by the submersibles. Immediately after retrieval all specimens were sorted, measured, sexed and fixed in $80 \%$ alcohol. 


\title{
FAMILY TAXONOMY
}

\author{
Order DECAPODA Latreille, 1802 \\ Infraorder CARIDEA Dana, 1852 \\ Superfamily BRESILIOIDEA Calman, 1896 \\ Family MIROCARIDIDAE fam. nov.
}

Diagnosis. Rostrum smooth; exopod rudimentary in maxilliped 3 and missing in pereopods; hook-like epipods present in maxillipeds 3 to pereopods 4 ; arthrobranchs at maxilliped 3 to pereopod 4; appendix interna rudimentary in pleopods $2-4$.

Composition. Mirocaris gen. nov.

\section{Description}

Mandible molar process slender, tip not subtruncate, separate from incisor process; palp 2-articled; first maxilla with two endites separated from each other; palp 1-segmented; second maxilla endites poorly separated, proximal endite divided into two equal lobes; first maxilliped with long exopod much overlapping endite, epipod present; second maxilliped pediform and flattened; 5-segmented, exopod and epipod present; third maxilliped 5-segmented, exopod rudimentary, without lash, epipod present.

Pereopods all with distinct segments; pereopodal exopods missing; epipods present on pereopods 1-4; pereopods 1 and 2 with chelae pectinate along cutting edges.

Phyllobranchs developed in two series: pleurobranchs associated with pereopods 1-5, and arthrobranchs at maxilliped 3 to pereopod 4 .

Pleopods 2-4 with rudimentary appendix interna; appendix masculina present.

Type genus: Mirocaris gen. nov.

\section{Remarks}

Chace (1992) combined all the genera of the Bresilioidea into the single family Bresiliidae, on the basis of the absence of pereopodal epipods and similar, though variable, mandibles. The discovery of a new genus possessing pereopodal epipods and undoubtedly belonging to the family Bresiliidae sensu lato (Chace, 1992) prevents the use of the first, most informative, character in the diagnosis of Bresiliidae, making the family too loosely defined. An alternative viewpoint on Bresiliidae sensu lato is that it consists of four separate families: Bresiliidae, Disciadidae, Alvinocarididae, and Mirocarididae.

The recognition of Bresiliidae and Disciadidae as separate families is not new, having been long accepted (e.g. Holthuis, 1955; Forest, 1973; Christoffersen, 1986, 1990). Following the discovery of the polychelate shrimp Pseudocheles Chace \& Brown, 1978 the family Disciadidae was synonymized with the Bresiliidae by Chace \& Brown (1978) rather than establishing a new family of one genus characterized by chelate pereopods 3-5, a character of uncertain significance. Subsequently, the concept of Bresiliidae sensu lato (Chace \& Brown) was followed by many carcinologists (see synonymy of the Bresiliidae). 
The discovery of Mirocaris gen. nov. poses the question of whether to rediagnose the Bresiliidae or to erect a new family, at the same time splitting the Bresiliidae sensu lato into several families. The first choice would create a family more morphologically diverse than any other decapod family. Therefore the second concept was chosen.

The family Mirocarididae differs from Bresiliidae and Disciadidae in having a rudimentary exopod on maxilliped 3, lacking pereopodal exopods, and having arthrobranchs at maxilliped 3 to pereopod 4 . It is separated from all bresilioidean families by the presence of well-developed hook-like epipods on maxilliped 3 to pereopod 4 and unique rudimentary appendix interna in pleopods $2-4$ (reduction of appendix interna is found in some members of the Alvinocarididae family to a lesser degree).

Other family level distinctions within the superfamily are clear from the following diagnoses. Identification as Bresilioidea was made by comparing with the detailed paper of Forest (1973), prior to the discovery of Pseudocheles. Only the most conspicuous characters were used for this family level separation: absence and/or strong reduction of main external organs (not form and detailed articulation character of their parts, etc). The recognition of Alvinocarididae as a separate family followed (Christoffersen, 1986) due to the character of the exopods, rudimentary on maxilliped 3 and absent on pereopods. Chace (1992) and Holthuis (1993) were followed in synonymizing Agostocarididae with Bresiliidae, because the characteristic articulation of the chela of the first pereopod, is probably generic character and associated with the cave-dwelling habit of this bizarre shrimp.

\section{Superfamily BRESILIOIDEA Calman, 1896}

Bresilioidea: Calman, 1896: 7; Thompson, 1965: 322 (part, without Nematocarcinidae); Holthuis, 1993: 68.

Bresilioida: Holthuis, 1955: 36.

Diagnosis. Rostrum when present denticulate or smooth; mandible with 2-articled palp, molar process not subtruncate and separated from incisor process; second maxilla with reduced palp; second maxilliped with serially positioned segments; pereopodal epipods when present with a strong hook at tip; first pereopods stronger than second, both with perfect chelae formed of one movable and one fixed fingers not hidden in tuft of setae; second pereopod with carpus entire, not subdivided; pleurobranchs associated with pereopods 1-5; pleopods 2-4 with appendix interna well-developed or rudimentary.

Composition. Bresiliidae: Calman, 1896; Disciadidae: Rathbun, 1902.

Alvinocarididae: Christoffersen, 1986; Mirocarididae: fam. nov.

Family BRESILIIDAE Calman, 1896

Bresiliidae: Calman, 1896: 7; Kemp, 1910: 35; Forest, 1973: 475; Chace \& Brown, 1978: 763 (part); Williams \& Chace, 1982: 145 (part); Christoffersen, 1986: 273; 1990: 94; Williams 
\& Rona, 1986: 460 (part); Burukovskii, 1988: 456 (part); Williams, 1988: 263 (part); Wicksten, 1989: 671 (part); Martin \& Hessler, 1990: 18; Williams \& Dobbs, 1995: 228.

Agostocarididae: Hart \& Manning, 1986: 411.

Diagnosis. Rostrum denticulate; exopods well developed in maxilliped 3 and present in pereopods 1-2 only; pereopodal epipods absent; arthrobranchs missing; appendix interna well developed in pleopods $2-4$.

Composition. Agostocaris Hart \& Manning, 1986; Bresilia Calman 1896.

Family DISCIADIDAE Rathbun, 1902

Discidae: Rathbun, 1902: 289.

Disciadidae: Kemp, 1920: 137; Forest, 1973: 475; Christoffersen, 1986: 273; 1990: 64.

Disciidae: Lebour, 1949: 1107.

Bresiliidae, part: (Calman, 1896) Chace \& Brown, 1978: 763; Williams \& Chace, 1982: 145; Williams \& Rona, 1986: 460; Burukovskii, 1988: 456; Wicksten, 1989: 671; Martin \& Hessler, 1990: 2; Chace, 1992: 70; Holthuis, 1993: 69.

Diagnosis. Rostrum denticulate or smooth; exopods well developed in maxilliped 3 and present in all pereopods; dactylus in pereopods 1-2 semicircular and compressed; no pereopodal epipods; arthrobranchs missing; appendix interna well developed in pleopods $2-4$.

Composition. Discias Rathbun, 1902; Lucaya Chace, 1939; Tridiscias Kensley, 1983; Pseudocheles Chace \& Brown, 1978.

\section{Family ALVINOCARIDIDAE Christoffersen, 1986}

Bresiliidae, part: (Calman, 1896) Williams \& Chace, 1982: 145; Williams \& Rona, 1986: 460; Williams, 1988: 263; Wicksten, 1989: 671; Martin \& Hessler, 1990: 2; Chace, 1992: 70; Holthuis, 1993: 69.

Alvinocarididae: Christoffersen, 1986: 273; Segonzac, de Saint-Laurent \& Casanova, 1993: 535.

Diagnosis. Rostrum when present denticulate or smooth; exopods rudimentary in maxilliped 3 and missing in pereopods; no pereopodal epipods; arthrobranchs at maxilliped 3 to pereopod 4; appendix interna developed in pleopods $2-4$.

Composition. Alvinocaris Williams \& Chace, 1982; Chorocaris Martin \& Hessler, 1990; Opaepele Williams \& Dobbs, 1995; Rimicaris Williams \& Rona, 1986. 
Family MIROCARIDIDAE fam. nov.

Bresiliidae: (non sensu Calman, 1896).

Diagnosis. Rostrum smooth; exopod rudimentary in maxilliped 3 and missing in pereopods; hook-like epipods present in maxillipeds 3 to pereopods 4 ; arthrobranchs at maxilliped 3 to pereopod 4; appendix interna rudimentary in pleopods 2-4.

Composition. Mirocaris gen. nov.

Incertae sedis

Encantada Wicksten, 1989. This genus cannot be assigned to a family, as the description is incomplete, based on single mutilated specimen.

Kirnasia Burukovskii, 1988. It is difficult to know where to refer this genus, because only one juvenile specimen was described (Burukovskii, personal communication).

\section{GENERIC TAXONOMY}

Mirocaris gen. nov.

\section{Description}

Integument thin, membranous. Rostrum smooth, lacking teeth, dorsally carinate in its anterior part. Antennal scale long and acute, pterygostomal spine rudimentary, trace of hepatic groove present (Figure 1A). Abdomen without dorsal carina, distally tapering, 2.1 times as long as carapace (including telson). Telson bearing 7-9 pairs of dorsolateral spines, posterior margin armed with several slender spines.

Eyes with cornea rounded, unfaceted, poorly pigmented.

Antennular peduncle with stylocerite long, narrow, and acute, overlapping first segment of antennular peduncle.

Antennal scaphocerite distally rounded, distolateral spine very short.

Mandible incisor process bearing six terminal and one subterminal teeth.

First maxilla with distal endite twice as long as proximal endite, both armed with rows of spines along distal 0.8 medial margin. Palp with oblique unbifurcated tip.

Second maxilla with distal endite twice as long as proximal endites, subtriangular. Palp reaching tip of distal endite. Scaphognathite elongate, distally narrowing, with terminal setae on posterior lobe longer than total length.

First maxilliped exopod longer than endite. Epipod long and narrow.

Second maxilliped with exopod long and narrow, not shorter than epipod.

Third maxilliped long and slender, ischium and merus distinct. Exopod nearly triangular. Epipod armed with a long sharp terminal hook.

First pereopods with enlarged chelae almost as long as wide in both sexes, no gape present.

Second pereopod with chela more slender than first, no gape present. 

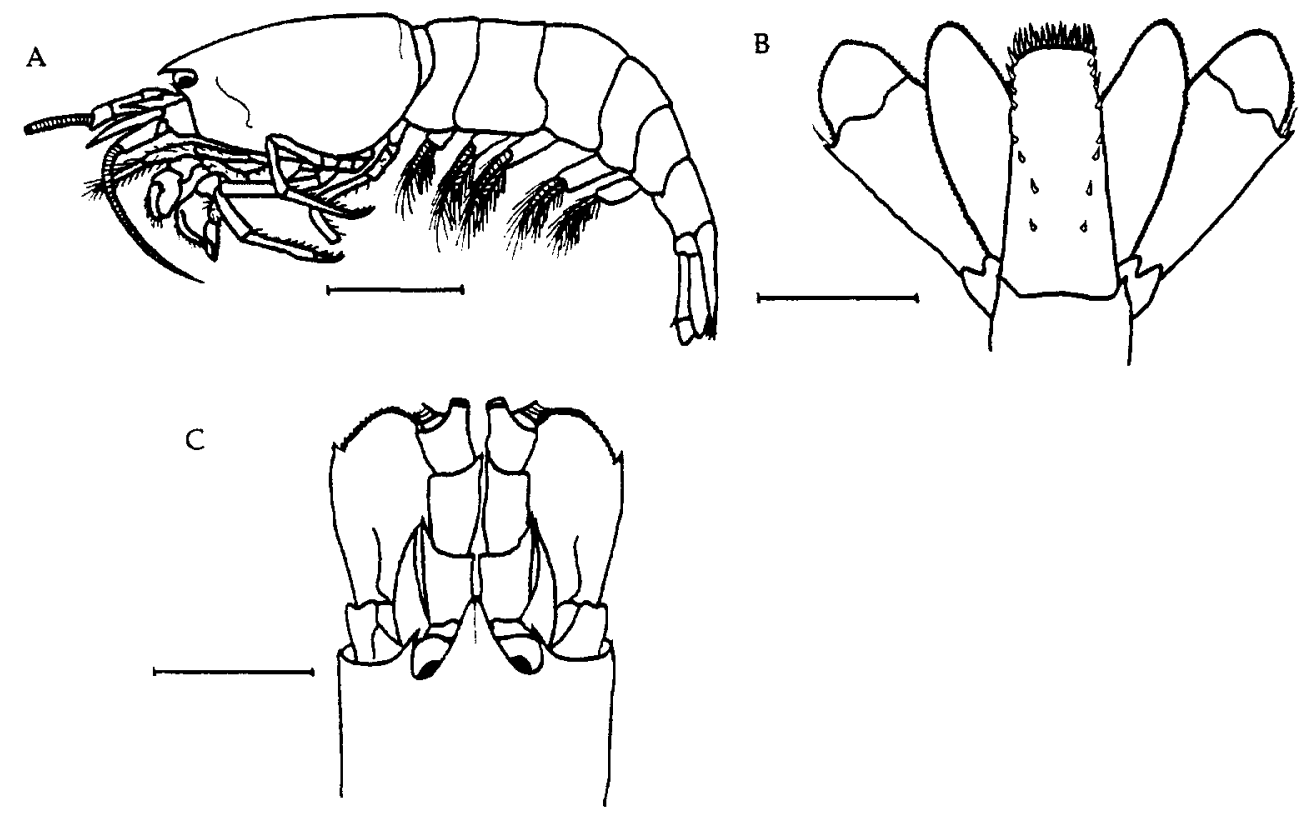

Figure 1. Mirocaris keldyshi. Female holotype: (A) lateral view; (B) telson and uropods, dorsal view; (C) anterior region, dorsal view. Scale bars: (A) $5 \mathrm{~mm}$; (B \& C) $2.5 \mathrm{~mm}$.

Third and fourth pereopods similar in form and size to each other, with propodus bearing teeth, dactylus armed with one terminal and several subterminal unguis.

Pleurobranchs progressively increasing in size posteriorly, arthrobranchs nearly equal in size except last smaller pair.

Pleopods with endopods of about half the length of the exopod in the first pair and subequal in second-fifth pairs. Appendix interna small in fifth pleopods and hardly visible in second to fourth pleopods.

Uropodal exopod bearing movable spine longer than and medial to small distolateral spine.

\section{Etymology}

The generic name is derived from the name of the Russian deep submersibles 'Mir-1' and 'Mir-2' (world, peace), and the Greek karis (shrimps). Gender feminine.

Type species: Mirocaris keldyshi sp. nov.

\section{Remarks}

Chorocaris fortunata (Martin \& Christiansen, 1995) undoubtedly belongs to this genus and to the family Mirocarididae. Its general appearance and morphological characters fit the above description of the genus. Epipods on maxilliped (Mxp) 3 to pleopod (Pp) 4 and rudimentary exopod on Mxp 3 were not mentioned in the description of C. fortunata and appear to have been overlooked by the authors. Chorocaris fortunata and 
Mirocaris keldyshi sp. nov. appear to be so closely related and differing from Chorocaris Martin \& Christiansen, 1990 (see family and generic taxonomy) and the genus Mirocaris is proposed to accommodate both species.

Composition. Mirocaris fortunata (Martin \& Christiansen, 1995) and M. keldyshi sp. nov.

Mirocaris keldyshi sp. nov.

\section{Material}

TAG location, $26^{\circ} 09^{\prime} \mathrm{N} 44^{\circ} 50^{\prime} \mathrm{W}, 30 \mathrm{~m}$ to the south-west from the point ' $00^{\prime}$, depth $3650 \mathrm{~m}$; baited trap installed 17 September 1994, Station 3369 and retrieved 22 September 1994, Station 3394 by the DRSV 'Mir'.

Holotype: female: carapace length $7.8 \mathrm{~mm}$, total length $27.5 \mathrm{~mm}$. Paratypes: females: carapace length $6 \mathrm{~mm}(1), 6.5 \mathrm{~mm}$ (1), $7 \mathrm{~mm}$ (2), $8 \mathrm{~mm}$ (3), $8.5 \mathrm{~mm}$ (5), $9 \mathrm{~mm}$ (3), $10 \mathrm{~mm}$ (1), $10.5 \mathrm{~mm}$ (1); males: carapace length $6 \mathrm{~mm}(1), 7 \mathrm{~mm}(5), 7.5$ (1).

All specimens are stored in the collection of the Oceanology Institute, Moscow, Russia. The following paratypes are to be transferred from the collection: one male, one female, to the Zoological Museum of University of Copenhagen; one male, one female, to the Museum National d'Histoire Naturelle, Paris, France; and one male, one female, to the Rijksmuseum van Natuurlijke Historie, Leiden, Netherlands.

\section{Description}

Carapace setose on first two thirds of its ventral margin. Rostrum subtriangular in cross-section, sharply pointed, dorsally convex and ventrally slightly concave, bearing a few apical setae and no spines, reaching half way along the first segment of antennular peduncle (Figure 1C). Blunt dorsal carina conspicuous along half anterior rostral margin. Antennal spine reaching two thirds of rostrum length and overlapping cornea, its tip directed mediodorsally.

Pleura in abdominal somites $1-4$ broadly rounded, with conspicuous posterior angle in fourth somite, with a posterior spine in fifth somite. Sixth somite 1.5 times as long as high. Telson elongate (Figure 1B), almost orthogonal, twice as long as wide in its widest proximal part, the latter 1.3 times as wide as distal part; its dorsal margin armed with eight pairs of spines of approximately equal size, the three anterior pairs closer to median line; posterior margin slightly convex, without sinus, armed with 15 spines.

Eyes without tubercules (Figure 1C), medially fused, their proximal quarter slightly pigmented.

Antennular peduncle (Figure 1C) overlapping distolateral spine of scaphocerite and reaching tip of blade. Stylocerite with tip directed medially, reaching $1 / 4$ length of second peduncular segment. Basal peduncular segment armed with long acute lateral spine equal to stylocerite; second segment with mediodistal blunt spine reaching as far as $1 / 4$ length of third segment. Length ratio of peduncular segments 1-2-3 measured on their medial margins 5:6:4, respectively. Flagellum about four-fifths of carapace length.

Antennal scale nearly twice as long as wide, distolateral spine somewhat blunt, 

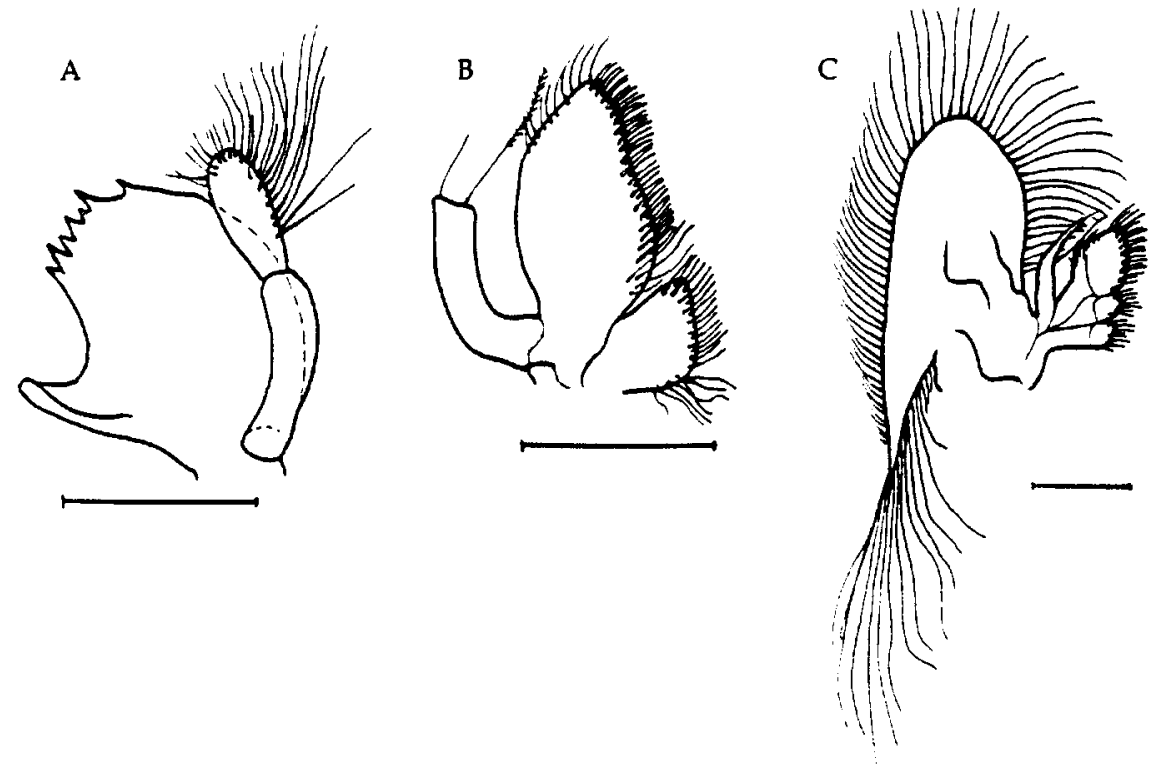

Figure 2. Mirocaris keldyshi. Female holotype: (A) left mandible; (B) left first maxilla; (C) left second maxilla. Scale bars: $1 \mathrm{~mm}$.

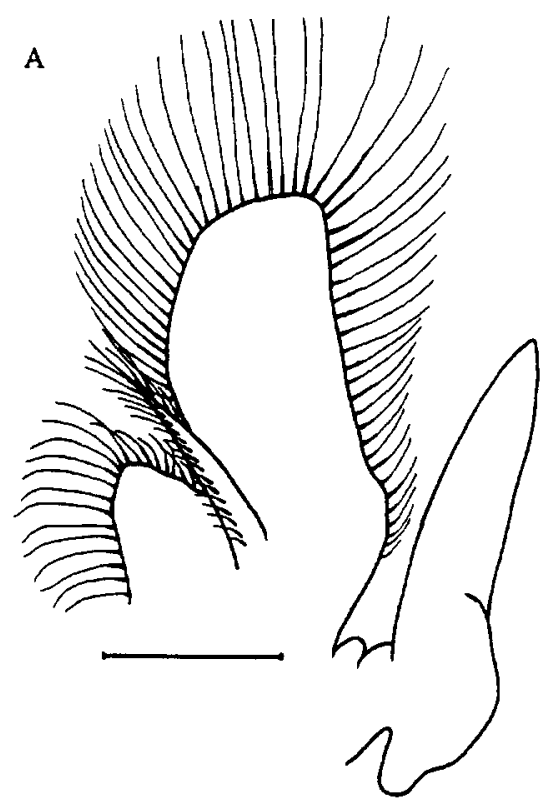

B

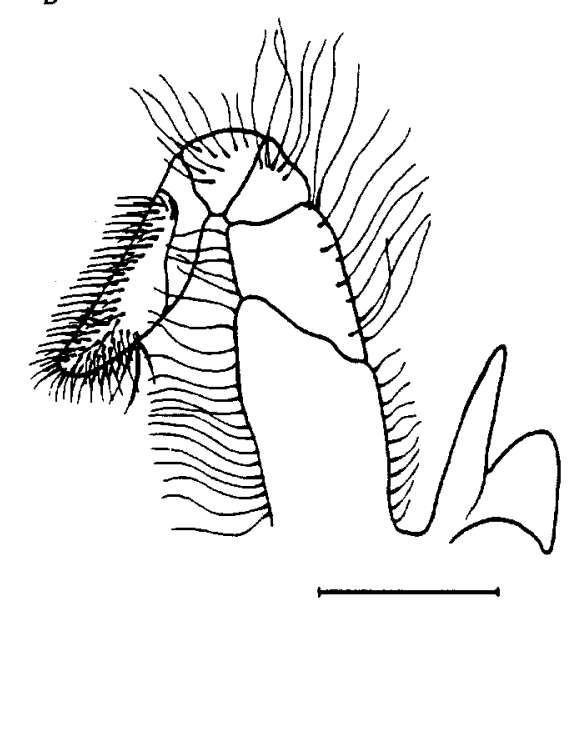

Figure 3. Mirocaris keldyshi. Female holotype: (A) left first maxilliped; (B) left second maxilliped. Scale bars: $1 \mathrm{~mm}$. 
reaching $1 / 4$ length of distal part of blade; anterior margin of scaphocerite broadly rounded. Antennal peduncle reaching to $2 / 3$ length of scaphocerite, basal segment with ventral, distal and median spines.

Mandibles (Figure 2A) with broad incisor processes bearing three shorter and three longer terminal teeth. Palp with distal segment bearing plumose setae in its distal half, the longest on the middle of the segment and one and a half times in length.

First maxilla with distal endite covered for $1 / 5$ of its proximal part and along $3 / 4$ of its distal lateral margin with longer plumose setae (Figure 2B). Palp bearing short lateral and very long plumose medial setae at the tip, the latter reaching tip of endite.

Second maxilla (Figure $2 \mathrm{C}$ ) with palp wide at its base, tapering to a long spout seta at the level of the distal part of the endite, bearing two long subapical setae; all sutures between segments visible. Scaphognathite with a rounded anterior lobe as wide as long, and a narrow triangular posterior lobe covered with shorter setae proximally and very long terminal setae (about ten) equal in length to the entire scaphognathite.

First maxilliped (Figure 3A) overlapped by palp bearing two rows of setae on its dorsal and ventral sides. Epipod with distinct proximal heel, about three times as long as wide in its proximal side.

Second maxilliped (Figure $3 \mathrm{~B}$ ) with segments covered with plumose setae. Distal segment separated from penultimate by oblique suture and bearing dense group of strong setae on 4/5 of its distal medial side; exopod twice as long as epipod.

Third maxilliped (Figure 4A) not overlapping antennal scale, with merus bearing a long stout spine at articulation with carpus. Distal segment with a row of strong setae along 4/5 of its distal ventral side, dorsal margin covered with more disperse and slender setae. Epipod (of Figure 5A type) covered with several plumose setae.

First pereopod (Figure $4 \mathrm{~B}$ ) reaching as far as third maxilliped. Ischium and merus covered with long irregular plumose setae along their ventral and dorsal sides. Carpus strongly curved $1 / 3$ along its proximal side, dorsally covered with plumose setae, armed with a long distal spine and several shorter distoventral spines positioned in a V-shape. Cutting edge of chela with spines dense and directed obliquely distad, fingers directed inward. Propodus bearing a seta on its dorsal side and spines in transverse oval patch on ventral side on the proximal part; fixed finger very wide and thick in its proximal half, flattened with strong distal setae. Dactylus as long and 3.5 times as narrow as the fixed finger in lateral view, covered with sensory short setae along half its dorsal margin. Epipod similar to that in the third maxilliped.

Second pereopod (Figure 4C) with ischium and merus covered with long plumose setae along their medial sides, the latter covered also along its lateral side. Ischium with long movable spine on distolateral side, $1 / 6$ of distance from flexor margin. Carpus covered with setae on both sides and armed with short distolateral processes. Chela with fingers of the same length as the palm, equal in size and armed with rows of spines directed distad. Few setae on lateral and distomedial margin of palm, sensory setae on half outer margins of both fingers. Epipod similar to that in third maxilliped.

Third and fourth pereopods with ischium and merus separated by distinct transverse junction and covered with a few short setae on their medial margins. Carpus shorter than merus, bearing setae and a distal process on its lateral side. Propodus with several 

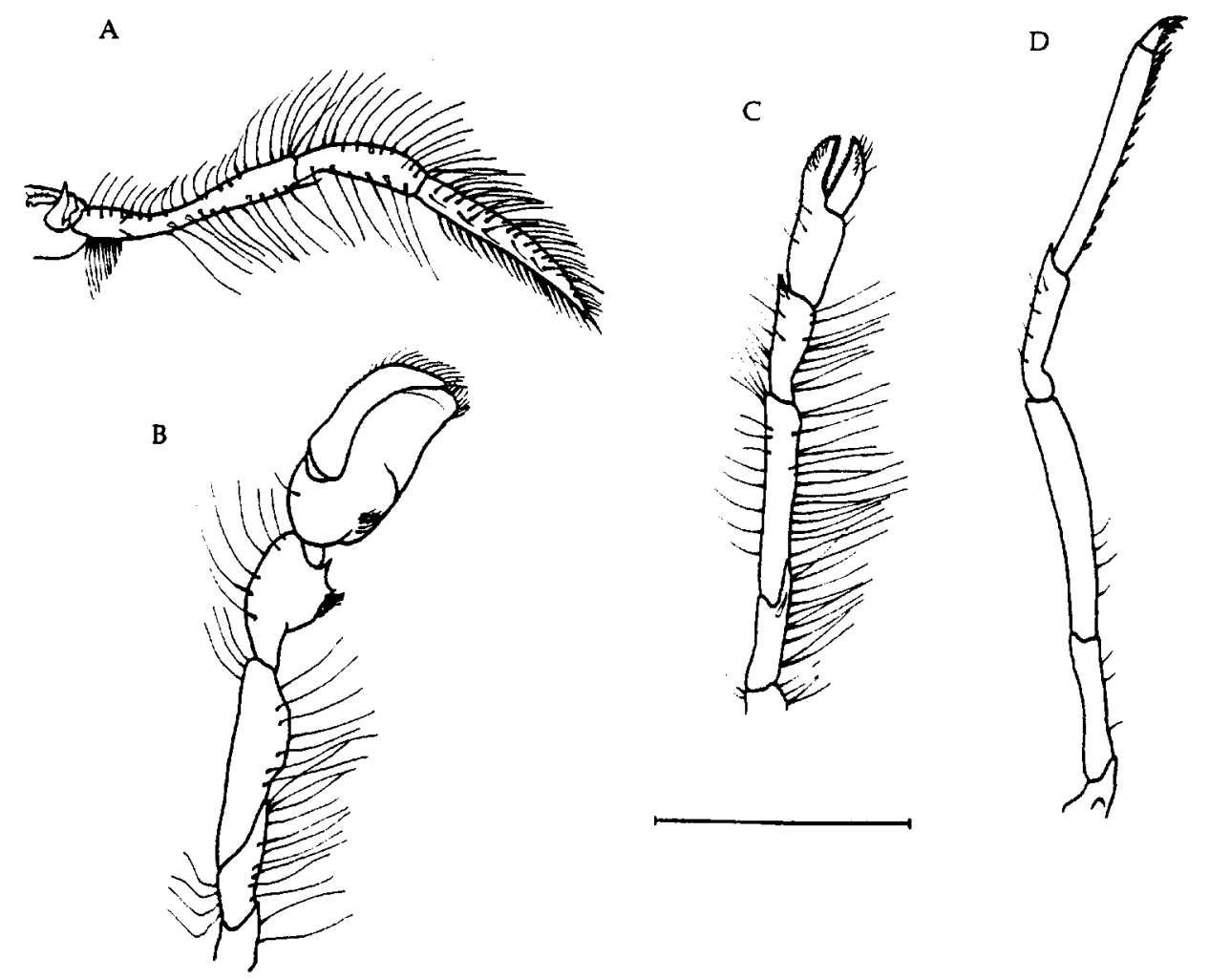

Figure 4. Mirocaris keldyshi. Female holotype: (A) left third maxilliped; (B) left first pereopod; (C) left second pereopod; (D) left fourth pereopod. Scale bars: $3 \mathrm{~mm}$.

spines widely spaced on the proximal part. Dactyl one-seventh the length of the propodus with a transverse row of tiny setae on the distal part, one apical, two subterminal hooks, and two smaller curved spines on its ventral surface. Epipods similar to that in third maxilliped.

Fifth pereopods broken at level of propodus, similar to respective parts of third to fourth pereopods.

The pleurobranchs have dorsal rami nearly equal to the ventral ones in the first pair, slightly longer and more voluminous in second-third pairs, and four times the size of the ventral rami in fourth-fifth pairs. In arthrobranchs, rami almost symmetrical and equal in size.

Pleopods 2-4 with appendix interna hidden between stronger and much longer setae in both sexes; of usual size, about $1 / 4$ endopod length and armed with several small terminal hooks in fifth pair. Appendix masculina three times as long and seven times as thick as appendix interna on second pleopod, armed with eight strong long spines nearly equal in size to appendix masculina.

Uropodal rami overlapping telson. Outer exopod ramus somewhat longer, with distinct diaeresis, movable spine five times as long as distolateral spine. 
A

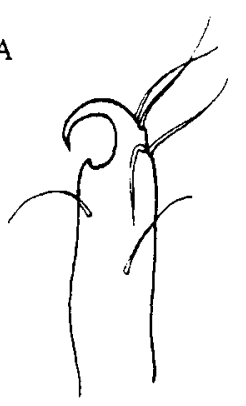

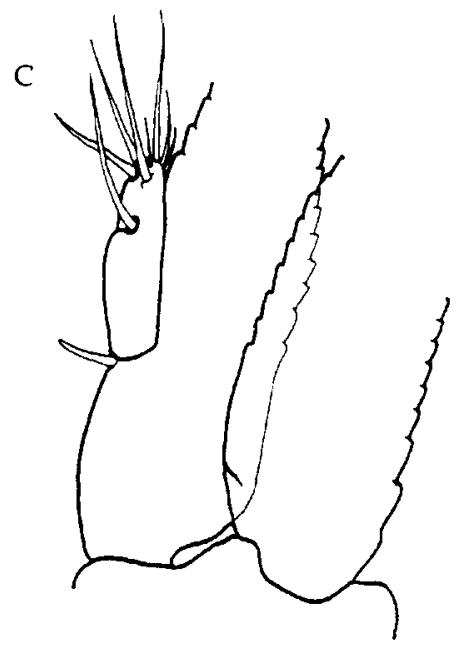

B

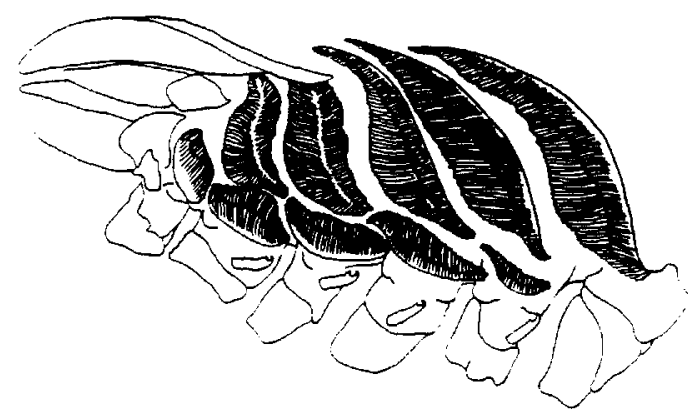

Figure 5. Mirocaris keldyshi. Male paratype: carapace length $7.2 \mathrm{~mm}$. (A) Epipod from left third pereopod; (B) thorax with carapace removed showing branchs, left lateral view; (C) right second uropod. Scale bars: (A) $0.2 \mathrm{~mm}$; (B) $2 \mathrm{~mm}$; (C) $0.5 \mathrm{~mm}$.

\section{Etymology}

Named after the RV 'Akademik Mstislav Keldysh', 'Keldysh' in short, in recognition of the ships contribution to knowledge of the deep-sea and, in particular, to hydrothermal vent biology.

\section{Colour}

Pinkish with irregular white spots in dead specimens brought to the surface.

\section{Variations}

Downwardly directed setae at the tip of the rostrum are absent in some specimens; the description of the posterior margin of telson is a synthesis of observations of all type specimens. The spines are very loose and easily broken during examination; the 
number ranges from 12 to 18 (never ten as figured for $M$. fortunata (Martin \& Christiansen, 1995)), although usually 15 , as in the holotype and paratype, with one unpaired medial spine. In contrast to many other decapod species, the first very massive chelae are of equal form and size in both sexes. Fifth pereopods are broken at the level of propodus in the type specimens, they are believed to be somewhat longer than two precedent pairs.

\section{Morphological remarks}

This species is very similar to Mirocaris fortunata (Martin \& Christiansen) from the Lucky Strike hydrothermal site. I have not been able to examine the holotype of that species. To avoid delay I decided to describe Mirocaris keldyshi as a separate species. It differs from $M$. fortunata in several characters but their reliability is variable, and future studies are needed to show the real taxonomic distance between the species. Table 1 shows the characters for distinguishing the species. Characters 1,4 , and 7 of $M$. fortunata are seen only on figure 2, Martin \& Christiansen, (1995) and may be related to the manner of drawing; spines (characters $5-6$ of $M$. fortunata) are not mentioned in the text (Martin \& Christiansen, 1995) nor figured, the characters 2 and 3 of $M$. fortunata are taken from the figure 2 of Martin \& Christiansen, (1995) and seem to be the most reliable for separation of the species.

Table 1. Distinguishing characters between Mirocaris fortunata (Martin E Christiansen, 1995) and Mirocaris keldyshi sp. nov.

Character

1. Palp in Mxp I with 2 distal

2. Ratio length/width in exopod of Mxp I

3. Ratio exopod length/epipod length in Mxp II

4. Carpus and merus in Mxp II

5. Spines on transverse oval place in proximal part of propodus in Pp I

6. Movable spine on ischium of Pp II

7. Number of posterior spines on telson
Mirocaris fortunata

spines (acc. to Figure 2)

3 (acc, to Figure 2)

1

fused (acc. to Figure 2)

absent

absent

10 (acc. to Figure 3)
Mirocaris keldyshi

plumose setae

2

1.5-2

distinct

present

present

12-18

$$
\text { Mxp, maxilliped; Pp, pleopod. }
$$

\section{Biological remarks}

Examination of gut contents shows Mirocaris sp. to be necrophagous, living mainly on remnants of more abundant Rimicaris exoculata. These are exuvia and corpses, the former being very abundant at the site: the contents of one of the sedimentation traps installed at the TAG location by Dr V.N. Lukashin, included several exuvia. Samples from biological traps provide evidence that Mirocaris keldyshi dwells at a distance of $\sim 30-70 \mathrm{~m}$ from the main smokers, at the very margin of the hydrothermal community, avoiding the close vicinity of the vent areas, either black smokers or shimmering waters. 
I am grateful to Professor M.E. Vinogradov (Institute of Oceanology, Russia) for his sustained efforts aboard DSRV 'Mir' to obtain deep-sea shrimps, and to the team of 'Mir' for the friendly atmosphere during the dives; my personal thanks to Dr Niel Bruce (Zoological Museum, University of Copenhagen) for revision of this manuscript and his advice. This work was supported by the Russian Fund for Basic Research, grant nos. 96-04-48333 and 96-05-64248.

\section{REFERENCES}

Burukovskii, R.N., 1988. New representatives of the family Bresiliidae (Crustacea, Decapoda) from the north-east Atlantic. Zoologicheskii Zhurnal, 67, 456-460. [In Russian.]

Calman, W.T., 1896. On deep-sea Crustacea from the south west of Ireland. Transactions of the Royal Irish Academy, 31, 1-20.

Chace, F.A., 1939. Reports on the scientific results of the First Atlantis Expedition to West Indies, etc. Preliminary descriptions of one new genus and seventeen new species of Decapod and Stomatopod Crustacea. Memorias de la Sociedad Cubana de Historia Natural Felipe Poey, 13, 31-54.

Chace, F.A. Jr, 1992. On the classification of the Caridea (Decapoda). Crustaceana, 63, 70-80.

Chace, F.A. Jr \& Brown, D.E., 1978. A new polychelate shrimp from the Great Barrier Reef of Australia and its bearing on the family Bresiliidae (Crustacea: Decapoda: Caridea). Proceedings of the Biological Society of Washington, 91, 756-766.

Christoffersen, M.L., 1986. Phylogenetic relationships between Oplophoridae, Atyidae, Pasiphaeidae, Alvinocarididae fam. nov., Bresiliidae, Psalidopodidae and Disciadidae (Crustacea Caridea Atyoidea). Boletim de Zoologia, 10, 273-281.

Christoffersen, M.L., 1990. A new superfamily classification of the Caridea (Crustacea: Pleocyemata) based on phylogenetic pattern. Zeitschrift fiir Zoologische Systematik und Evolutionsforschung, 28, 94-106.

Forest, J., 1977. Un groupement injustifie: la superfamille des Bresilioida. Rémarques critiques sur le statut des familles réunies sous le nom (Crustacea Decapoda Caridea). Bulletin du Muséum National d'Histoire Naturelle, Zoologie. Paris, 332, 869-888.

Hart, C.W. Jr \& Manning, R.B., 1986. Two new shrimps (Procarididae and Agostocarididae, new family) from marine caves of the western North Atlantic. Journal of Crustacean Biology, 6, $408-416$.

Holthuis, L.B., 1955. The recent genera of the Caridean and Stenopodidean shrimps (Class Crustacea, Order Decapoda, Supersection Natantia) with keys for their determination. In Zoologische Verhandelingen, vol. 26 (ed. Professor Dr H. Boschma), pp. 1-157. Leiden: Brill.

Holthuis, L.B., 1993. The recent genera of the caridean and stenopodidean shrimps (Crustacea, Decapoda) with an appendix on the order Amphionidacea. Leiden: National Natuurhistorisch Museum.

Kemp, S., 1910. The Decapoda Natantia of the coasts of Ireland. Scientific Investigations of the Fisheries Branch. Department of Agriculture for Ireland, 1908, 1, 1-190.

Kemp, S., 1920. Notes on the Crustacea Decapoda in the Indian Museum. XIV. On the occurrence of the Caridean genus Discias in Indian waters. Records of the Indian Museum, 19, 137-143.

Kensley, B., 1983. New records of bresiliid shrimp from Australia, South Africa, Caribbean, and Gulf of Mexico (Decapoda; Natantia: Caridea). Smithsonian Contributions to Zoology, 394, 1-31.

Lebour, M.V., 1949. Some new Decapoda Crustacea from Bermuda. Proceedings of the Zoological Society of London, 118, 1107-1117.

Martin, J.V.\& R.R. Hessler, 1990. Chorocaris vandoverae, a new genus and species of hydrothermal vent shrimp (Crustacea: Decapoda: Bresiliidae) from the western Pacific. Contributions in Science. Los Angeles County Museum of Natural History, 417, 1-11.

Martin, J.W. \& Christiansen, C., 1995. A new species of the shrimp genus Chorocaris Martin \& Hessler, 1990 (Crustacea: Decapoda: Bresiliidae) from hydrothermal vent fields along the Mid-Atlantic Ridge. Proceedings of the Biological Society of Washington, 108, 220-227.

Rathbun, M.J., 1902. Papers from the Hopkins-Stanford Galapagos Expedition 1898-1899. VIII. Brachyura and Macrura. Proceedings of the Washington Academy of Sciences, 4, 275-292.

Segonzac, M., Saint Laurent, M. de \& Casanova, B., 1993. L'enigme du comportement trophique des crevettes Alvinocarididae des sites hydrothermaux de la dorsale medio-atlantique. Cahiers de Biologie Marine, 34, 535-571. 
Thompson, J.R., 1967. Comments on phylogeny of section Caridea (Decapoda: Natantia) and the phylogenetic importance of the Oplophoroidea. Proceedings of Symposium on Crustacea, Marine Biological Association of India, Part 1, 314-326.

Wicksten, M.K., 1989. Encantada spinoculata, a new genus and species of shrimp from the Galapagos Islands (Caridea: Bresiliidae). Journal of Crustacean Biology, 9, 667-671.

Williams, A.B., 1988. New marine decapod crustaceans from waters influenced by hydrothermal discharge, brine, and hydrocarbon seepage. Fishery Bulletin. National Oceanic and Atmospheric Administration. Washington DC, 86, 263-287.

Williams, A.B. \& Chace, F.A., 1982. A new caridean shrimp of the family Bresiliidae from thermal vents of the Galapagos Rift. Journal of Crustacean Biology, 2, 136-147.

Williams, A.B. \& Dobbs, F.C., 1995. A new genus and species of caridean shrimp (Crustacea: Decapoda: Bresiliidae) from hydrothermal vents on Loihi Seamount, Hawaii. Proceedings of the Biological Society of Washington, 108, 228-237.

Williams, A.B. \& Rona, P.A., 1986. Two new caridean shrimps (Bresiliidae) from a hydrothermal field on the Mid-Atlantic Ridge. Journal of Crustacean Biology, 6, 446-462.

Submitted 27 March 1995. Accepted 8 March 1996. 